\title{
Physiographic Characteristics along the Ibex Protectorate: Remote Sensing Application, Hotet Bani Tamim, Central Saudi Arabia
}

\author{
Mansour H. Al-Hashim ${ }^{1}$ Maysa M.N. Taha² Hesham M. El-Asmar ${ }^{3} 4^{*}$
}

1. Department of Geology and Geophysics, College of Science, King Saud University, Saudi Arabia

2. Department of Geology, Faculty of Science, Helwan University, Egypt

3. Advisor at Deanship of admission and registration, King Saud University,

4. Department of Geology, Damietta University, New Damietta City 34517, Egypt

* E mail of the corresponding author: hmelasmar@yahoo.com

\begin{abstract}
Tuwiaq plateau is one of the most characteristic physiographic components of central Saudi Arabia. The Middle Jurassic limestone was the result of the natural harmony between the Tethys sedimentation, tectonics, and climate. The plateau was studied within the Ibex Protectorate of Hotet Bani Tamim area. Remote sensing applications on satellite images of 2019 were able to measure the geomorphology, distinguish the sedimentary units, and emphasized the role of tectonics in dividing the plateau to step-like escarpment, elevated from $1080 \mathrm{~m}$ at Al-Onouk the extreme northwest to $600 \mathrm{~m}$ at Al-Hulwah with an average slope of $0.8 \mathrm{cmm}^{-}$ 1. The slope at catchment reaches up to $70^{\circ}$ while at the downstream not more than $16^{\circ}$. Two basins are detected at the Ibex protectorate, these are Wadi Meta'am basin and Wadi Bowydan- Nokhailan basin who down flow into Wadi Meta'am and Wadi Berek respectively). Wadi Meta'am derives its water through three tributaries Al-Ghaba, Ghafar, and Al-Agmaa, while Wadi Bowydan, on the other hand, cuts deeper and drain water with Wadi Nokhailan downstream to Wadi Berek. The high-density dendritic drainage pattern with $5^{\text {th }}$ and $6^{\text {th }}$ order tributaries support the vulnerability of the area to flash flood hazards. The heavy rains were able to sculpt such an amazing geomorphosite and leave its finger prints in the form of deep streams (about 140m depth), channel lags of cobbles and pebbles, Quaternary thick colluvium, water-saturated soils, and karstic features such as the small pool, calcretes and travertines. The present study seeks the importance to schedule the area within the program of development according to the vision 2030 and to add among the geoheritage sites
\end{abstract}

Keywords: Remote sensing, GIS, Ibex Protectorate, physiography, land classification

DOI: $10.7176 / \mathrm{JEES} / 9-11-04$

Publication date: November $30^{\text {th }} 2019$

\section{Introduction}

Saudi Arabia $\left(16^{\circ} 83^{\prime}-32^{\circ} 34^{\prime} \mathrm{N}\right.$ and $\left.34^{\circ} 36^{\prime}-56^{\circ} 18^{\prime} \mathrm{E}\right)$ occupies the major part of the Arabian Peninsula with a total area of approximately 2.25 million $\mathrm{km}^{2}$ (Fig. 1). It is within an arid to semi-arid climate zone, yet it has several characteristic sites with rich and unique geodiversity associated with an ever-changing depositional environments and tectonics. One of these sites is the Ibex Protectorate which was established by the National Commission for Wildlife Conservation and Development (NCWCD) as an effort to protect the biodiversity of the area from increasing anthropogenic activities such as pollution, grazing, hunting, and wood gathering as well as to protect the habitats of rare and endangered species (Fahmy \& Hassan, 2005; Al-Huquial \& Al-Turki, 2006). The Ibex Protectorate is now among 15 other protectorates which the NCWCD manages (Al-Khamis et al. 2012).

The Ibex Protectorate is located in the Hotat Bani Tamim area $\left(23^{\circ} 12^{\prime} \mathrm{N}, 46^{\circ} 15^{\prime} \mathrm{E}\right)$, approximately $180 \mathrm{~km}$ south of Riyadh (Fig. 1). Named after the Nubian Ibex capra, the Protectorate was established in 1988 with a total area of $2369 \mathrm{~km}^{2}$. Two major wadis are present in the study area; Wadi Meta'am and Wadi Bowydan which discharge their water to flat low-lying areas at AlHulwah and Bowydan, respectively, both of which belong to Wadi Berek where several square kilometers of land are cultivated according to discharged water. The Ibex protectorate is accordingly classified into two parts Ibex 1 related to Wadi Meta'am basin and Ibex 2 related to Wadi Berek basin (Qais Al-Hazaa, personal communication). However, no systematic land classification has ever been made in the Ibex Protectorate area. The present geo-environmental study aims to update knowledge and shed light on the Ibex Protectorate, with a focus on land cover classification and physiographic characteristics of the area by using a remote sensing and GIS approaches supported by field verification. 

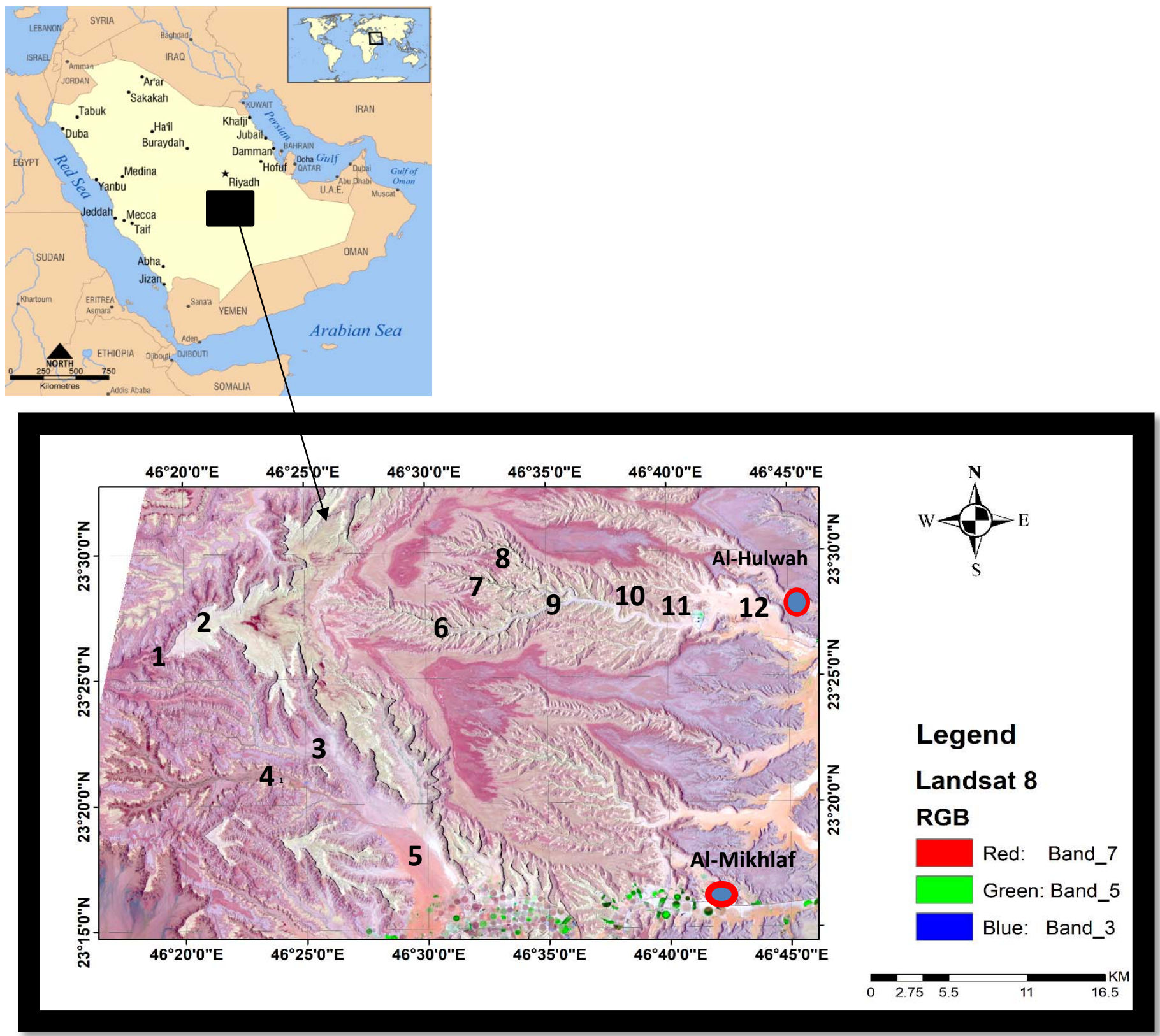

1. Al-Onouk 2. Abu Kaff 3. Wadi Bowydan 4. Wadi Nukhailan 5. Wadi Berek 6. Wadi Al-Ghaba 7. Wadi Ghafar 8. Wadi Al-Agam 9. Al-Molkatt 10. Gassat Al-Korinah 11. Wadi Meta'am 12. Wadi Meta'am Store lake

Figure 1. Landsat 8 image showing the main location and sites visited during filed work at the Ibex Protectorate.

Remote sensing and GIS techniques have been actively employed in the investigation of physiographic elements and land cover types and attributes (Herold et al. 2002; Gaber et al. 2016; Arnous et al. 2017; Chen et al. 2018). Their rapid adaptation is mainly due to their cost effectiveness and their ability to provide regional- to global-scale geographic data in a timely manner; as well as their ability to overcome accessibility issues that are commonly associated with field surveys (Hereher et al. 2012; Abuelgasim \& Ammad 2019). In addition, maps produced by the utilization of remotely sensed data are of high spatial resolution, making them powerful and capable tools for mapping, identifying, and refining physiographic features on relatively small scales (down to $100 \mathrm{~m}$ by $100 \mathrm{~m}$ ) which may not be discernible otherwise (Breeze et al. 2015). As a result, remotely sensed data are being utilized worldwide among scholars in a diverse range of study areas for the purpose of assessment, evaluation, and classification of physiographic features and land cover types, including mapping soil salinity (Eldeiry \& Gracia 2010; Abbas et 
al. 2013; Abuelgasim \& Ammad, 2019); mapping drainage systems (Ghoneim \& El-Baz, 2007; El Bastawesy et al. .2013; Breeze et al. 2015); mapping land cover distribution and attributes (King 2002; Erener et al. 2011); and mapping potential geoarchaeological sites (Fernández et al. 2016; Monterroso-Checa 2017).

\subsection{Geologic setting}

Jurassic rocks are exposed in central Saudi Arabia at Riyadh area, making a convex belt that bifurcates to the northwest and to the south. These rocks are represented in the area by the Shaqra Group, which is arranged into seven formations, in an ascending order, the Marrat, Dhruma, Tuwaiq Mountain Limestone, Hanifa, Jubaila, Arab, and Hith formations (Carrigan et al. 1995). The outcrop extends approximately $1000 \mathrm{~km}$ with a width of less than $85 \mathrm{~km}$. The total thickness of the rocks in Riyadh area is 1100 $\mathrm{m}$, reflecting the most proximal point to the Tethys Sea (Al-Asa'ad 2004).

Tuwiaq Mountain Limestone is a monoclinal sedimentary plateau which is a major constituent of physiographic feature of the Arabian Peninsula (Vincent 2008). The Middle Jurassic Tuwaiq Mountain Limestone represents a narrow belt that intersects the Najd plateau of central Arabia, a region dominated by many west-facing Jurassic cuestas extending roughly 1,600 km from Al-Nafud in the north to the Empty Quarter in the south and across Wadi ad-Dawasir (Powers et al. 1996). It has an average height of $600 \mathrm{~m}$ and an altitude of $800-1000 \mathrm{~m}$ a.s.l.

The maximum thickness of the Tuwaiq Mountain Limestone of $250 \mathrm{~m}$ is reached at its central part in Nisah area (lat. $24^{\circ}$ $150^{\prime} \mathrm{N}$ ), and the formation attains a thickness of approximately $45-60 \mathrm{~m}$ at its northern and southern extremities. The lowermost part of Tuwaiq Mountain Limestone consists of fine-grained, clayey limestone interbedded with calarenites and bioturbated, nodular limestone. The Middle part is slightly bioturbated, fine-grained to gravelly fossiliferous limestone with some isolated colonies. The uppermost part is comprised of extensive fossiliferous limestone and calcarenites, and contains silicified stromatoporoids and corals, well exposed in the center of the basin. The basin is bordered on its sides by several narrow wadis such as Wadi Hanifa.

\subsection{The aims}

The present study aims to analyze the remote sensing data using different applications supported with field observation to: (1) determine the adequacy of Tethys sedimentation, tectonics, and climate in sculpting such interesting geomorphosite, (2) determine the physiographic characteristics of the area and distinguish different discharge basins, (3) distinguish different sedimentary units and lithofacies characteristics, and (4) evaluation of flash flood hazards that may threaten the area.

\section{Methods}

\subsection{Image enhancement and classification}

For the current investigation, data obtained from the Landsat 8 satellite (Path 165/Row 44, July 22, 2019) have been processed and analyzed by ENVI 5.3 software. Six reflective bands (1-5 and 7) with a spatial resolution of $30 \mathrm{~m}$ and a panchromatic band (8) with a resolution of $15 \mathrm{~m}$ were used.

Earth's surface physical parameters and the atmosphere exhibit discrepancies that are dependent on the space-time remote sensing scales or ground based techniques used (Herold et al., 2002). These monitoring methods are built on the notion that land cover variations lead to variations in the spectral signals of the affected surface. The accuracy of the results is related to the adopted processing method such as geometric correction, spectral enhancement, and image classification, among others (Foody 2003, Tamouk et al. 2013).

Images are processed by several enhancement techniques with the objective of making them more suitable for particular applications and more effective in displaying visual information. In fact, enhancement techniques facilitate the extraction of visual information from images. Consequently, any variations in the features of an image will accentuate certain visual information pertaining to the area of interest by amplifying small differences and making them more discernible (Lillesand et al. 2004). The main concept upon which the multi-spectral computer classification was built is that surface features display different spectral signatures in different areas of the electromagnetic spectrum. Consequently, surface features are distinguished by the displayed signatures, and an image with a new set of categories is produced.

Pixels of multi-spectral images can be automatically categorized into different land cover themes, a process known as image classification. A key element of any image classification process is the employment of sample images of the spectral signatures of all features covered by the original images. Sample images should emphasize the difference between classes and thus enable the software program to assign point data to these classes. Therefore, classification systems are divided into two typesunsupervised and supervised classifications. For this study, an arbitrary set of classes representing all kinds of surface features 
was selected, and an unsupervised classification system was applied to the satellite data of the area. Supervised classification systems require specification of all ground cover types in the scene using training samples (Lillesand et al. 2004).

\subsection{Digital elevation model (DEM)}

Surface characteristics of the study area were mapped using data acquired by the Shuttle Radar Topography Mission (SRTM) with $30 \mathrm{~m}$ spatial resolution. This resolution range is the most suitable for national scale mapping. National terrain of Saudi Arabia was delineated based on political boundaries, and a clip of USGS GTOPO_U30 topographic data in the digital elevation model (DEM) was obtained. By utilizing the resulting DEM, different GIS layers were produced using ArcGIS 10.3 software. For terrain analysis, several layers of base maps (e.g., elevation zones, drainage networks) were included in the GIS layers. Image processing was performed using ENVI's band math function. The ENVI 5.3 software opens SRTM DEM files as ENVI-format image files that contain missing data points. These mission data points were subsequently corrected for their missing values which were then replaced by values interpolated from valid neighboring pixels. A new file encompassing all processed data points is generated by the software, whereas the original file is automatically saved.

\subsection{Image Processing}

The color composition of Landsat data is used for displaying image data files because these image data are directly related to the brightest values in the color spectrum. Bands can be systematically assigned to be displayed with either red (R), green $(G)$, or blue (B). For instance, a natural color simulated image will approximate the colors that would appear to the observer, whereas false colors will allow the analyst to pick up the data bands that would not otherwise appear to the same observer. Bands 7 (red), 5 (green), and 3 (blue) are represented in the composite image data for 2019 (Fig. 1).

\subsection{Image Enhancement}

\subsubsection{Band Ratio}

Band ratios of satellite images refer to the mathematical relations and ratios among the available bands within these images. Calculation of band ratios facilitates the determination of the distribution and intensity of specific features, either emission or absorption, in a semi quantitative way (Drury 2001). Band ratios are, therefore, commonly utilized in the enhancement process of the spectral discrepancies between bands as well as to minimize topographic effects (Gaber et al. 2016). An image containing relative band intensities can be generated by dividing one band by another, a process which further highlights the spectral differences between the bands. False color composite helps and facilitates the detection of and discrimination between color variations for the exposed rock units without enhancement processes (Mather 1999). Band ratios of Landsat-8 (6/7, 6/4, 4/2) were performed for precise identification and mapping of the rocks units.

\subsubsection{Principal component analyses (PCA)}

This image processing procedure compresses information of the original bands and eliminates data redundancy in images by means of processing different sets of multi-band data with an ultimate aim of enhancing the spectral discrimination capability of terrestrial materials (Curran 1985; Crosta \& Moore 1989; Loughlin 1991; Dewidar \& Frihy 2003). PCA of the Landsat-8 data of Ibex protectorate was applied. A set of three-band PC color composites was created. Input images with false color composite were used to display all components in the form of PCs. Statistical analysis reveals that PC321 yielded the most positive correlations in bands 321 and 743 for red, green and blue, respectively.

\subsection{Image classification}

Image classification is widely used as a tool for extracting thematic information of specific targets. In the current study, rock units are the main targets to be extracted using a suitable image classification method. This technique is primarily used to display different land categories by arranging image pixels into meaningful groups (Jensen 1995). This mapping process is built upon two statistical methods: supervised and unsupervised (fully automated) image classifications in which classes are either manually supervised or automatically supervised, respectively.

In the case of automatically supervised image classification, the software controls the analysis, and calculates spectral signatures which then are used in the classification process (Gaber et al. 2016). Each spectral signature should represent a class that does not necessarily represent actual surface features which are depicted by the original image. Fifteen classes are automatically determined some classes may merge, while others may need to be deleted. The supervised classification, in contrast, analyzes selected pixel groups within the image as to reflect the characteristics of individual classes (Gaber et al. 2016). Supervised classification was conducted via field investigation of the study area, during which information from more than 20 ground checkpoints was collected and digital geologic map maps were utilized. 

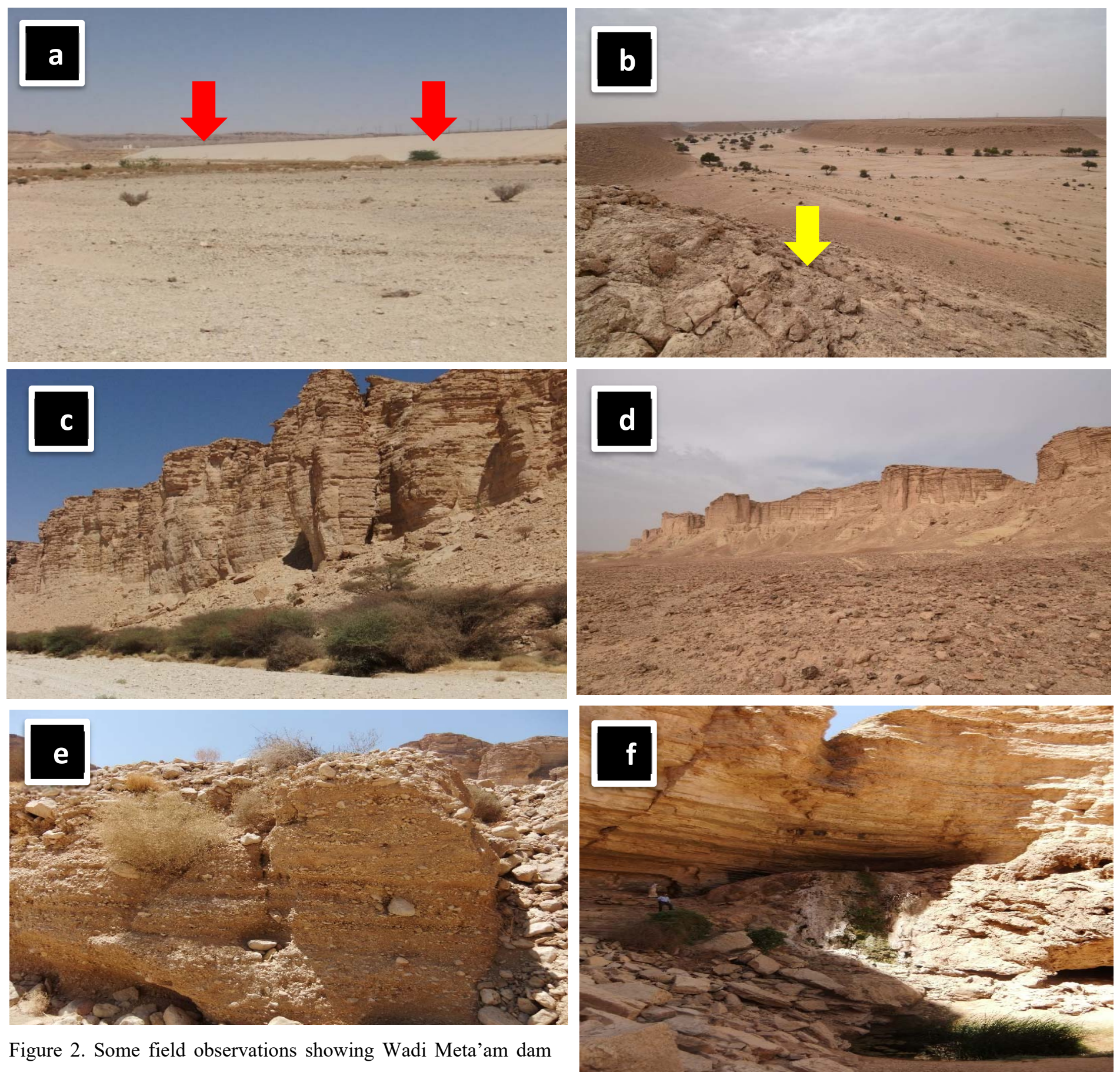

Figure 2. Some field observations showing Wadi Meta'am dam 930m long (red arrows), at the wide downstream (a) with slopes of travertine and talus (yellow arrows) (b). The Tuwaiq Plateau showing the cuestas with height more than 60 with detrital gravels and pebbles (c, d), and thick Quaternary colluvium of alternations of boulders and gravels with mud sediments (e). The effect of heavy rains leave the prints on the down cuts of wadis, it is also supported by the presence of karstic deposits (f, g) such as travertine and calcrete. The fissure through the limestone possibly yield fresh water pool (close up at g) through perched water table with fresh water Adiantum capillus (Veneris).

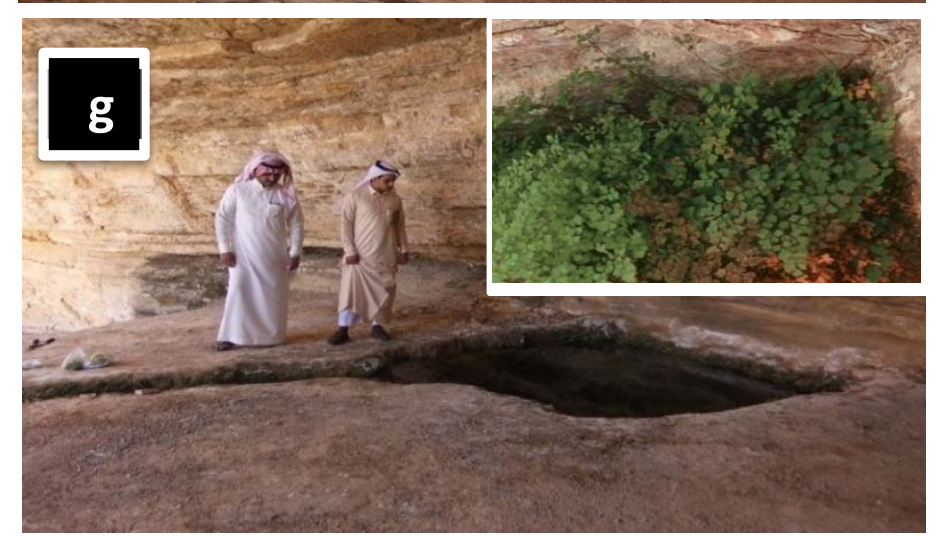




\section{Results and Discussion}

Field observations (Fig. 2) shows that the study area at the ibex protectorate is a unique geomorphosite in which the rains were able to sculpt exquisite fine art painting and confirm to which extent the climate played e very important role in shaping such natural museum. The area entirely composed of limestones that belong to the Tuwaiq plateau. Most rains crossed Al-Onouk escarpment (Fig. 1) the water accumulates at Abu Kaff escarpment (Fig. 1). The water then distributed along the plateau to form different basins of which two are the subject of this study. These are Wadi Meta'am basin and Wadi Bowydan- Nokhailan basin who down flow into Wadi Meta'am and Wadi Berek respectively. The down streams are very wide composed of wadi lag detritus of gravels and pebbles, with talus on slopes (Fig. 2a, b). At Wadi Meta'am a dam with $930 \mathrm{~m}$ length was constructed to store water that was threatening Al-Hulwah (Fig. 2a). Deep cuts observed through the limestone plateau for more than $140 \mathrm{~m}$ with steep escarpments (Fig. 2c, d). The heavy and thick deposition of Quaternary colluvium that composed of alternations of boulders and gravels with mud sediments (Fig. 2e) deposited across the streams confirm the rule of heavy rains that able to erode and transport these kind of heterogeneous sediments. Such wet climate is supported by the presence of karstic deposits (Fig. 2f, g) such as travertine and calcrete. The karst geomorphic features were recorded in many parts of the Tuwaiq limestone (Abd El-Aal 2017) The fissure through the limestone possibly yield fresh water pool (Fig. 2g) through perched water table with fresh water Adiantum capillus (Veneris) (Al-Olayan 2015).

The physiographic characteristics of the Ibex protectorate were investigated by delineating the topographic slope and aspect of the area. The contour map (Fig. 3) shows that the region has a rugged topography with elevation of up to 1080m at Al-Onouk with an average elevation of approximately 600-700m near Al-Hulwah (Figs.1, 3). The slope gradient directly influences the formation of drainage networks, and is, in turn, influenced by climatomorphic processes and rock resistance. The slope gradient is linked to the runoff speed which means it influences the required time for rain water to enter in the stream network of the basin (Villela \& Mattos 1975; Magesh \& Chandrasekar 2012; Gayen et al. 2013). Digital elevation model (DEM) data with 30-mresolution and ArcGIS 10.3 were utilized in the preparation of the slope map of the study area. The degree of basin slope of both basins Meta'am and Wadi Bowydan catchment varies between $0^{\circ}$ and $70^{\circ}$ (Fig. 4). There is a high slope gradient in both the eastern and western escarpments of the Tuwiaq plateau, causing rapid runoff and increasing erosion rates along with low recharge potential. On the other hand, most down streams have a general slope not more than $16^{\circ}$ (Fig. 4). The aspect map of slope shows that Wadi Meta'am basin trends E-NE, while the basins of Wadi Bowydan trends S-SE (Fig. 5). Ruggedness number is related to the drainage density and basin relief (Strahler 1968). The basin ruggedness of the study area numbers ranging between 0.08 and 7.29 .

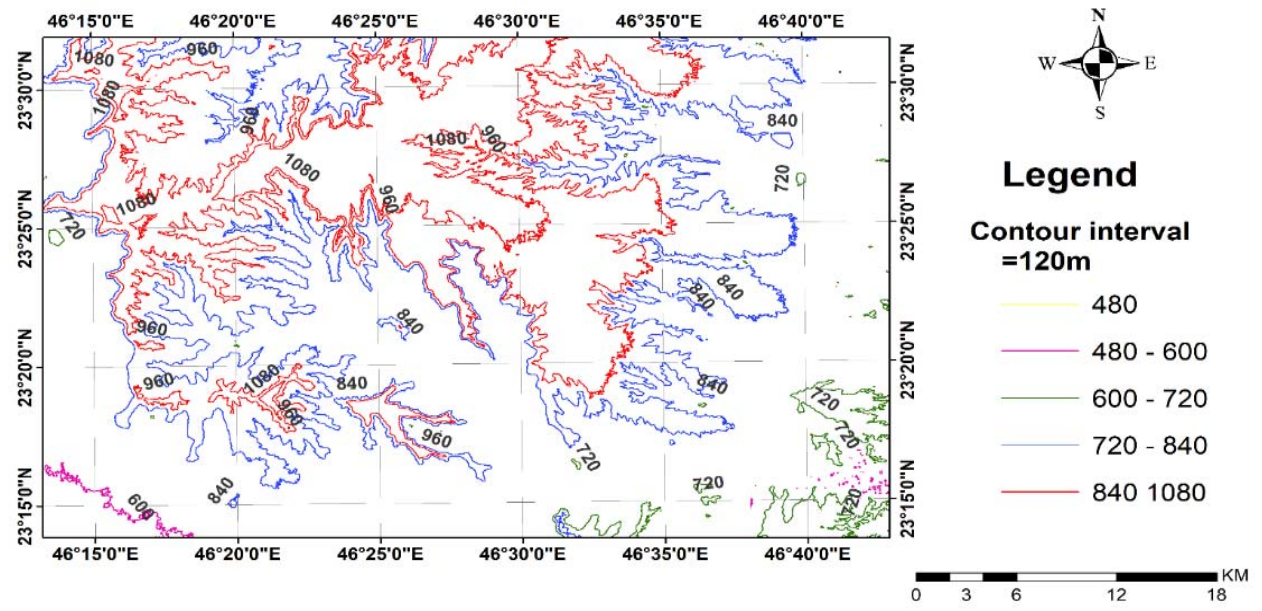

Figure 3. Contour map for the study area with $120 \mathrm{~m}$ interval showing the elevation of the upstream "red contours" at $1080 \mathrm{~m}$ and the downstream "green contours" $700 \mathrm{~m}$

The ratio of total length of streams to the basin area is known as the drainage density. A high drainage density is characterized by highly dissected catchment with a rapid hydrologic response to rainfall, whereas a low drainage density reflects a poorly drained basin with a relatively slow hydrologic response to rainfall (Melton 1957). Surface runoff and associated output of sediment and water are affected by the drainage density (Chorley 1969). At Wadi Meta'am basin, the average drainage density is $3.1 \mathrm{~km}^{-1}$, while at Wadi Bowydan -Nokhailan basin the average drainage density is $2.4 \mathrm{~km}^{-1}$ (Fig. 6). Another concept is the stream frequency which represents the total number of stream segments of each unit area. The lesser the stream frequency and drainage density in a basin, the slower the runoff is. Therefore, basins with low to moderate drainage density and stream frequency are less prone to flooding (Carlston 1963). 


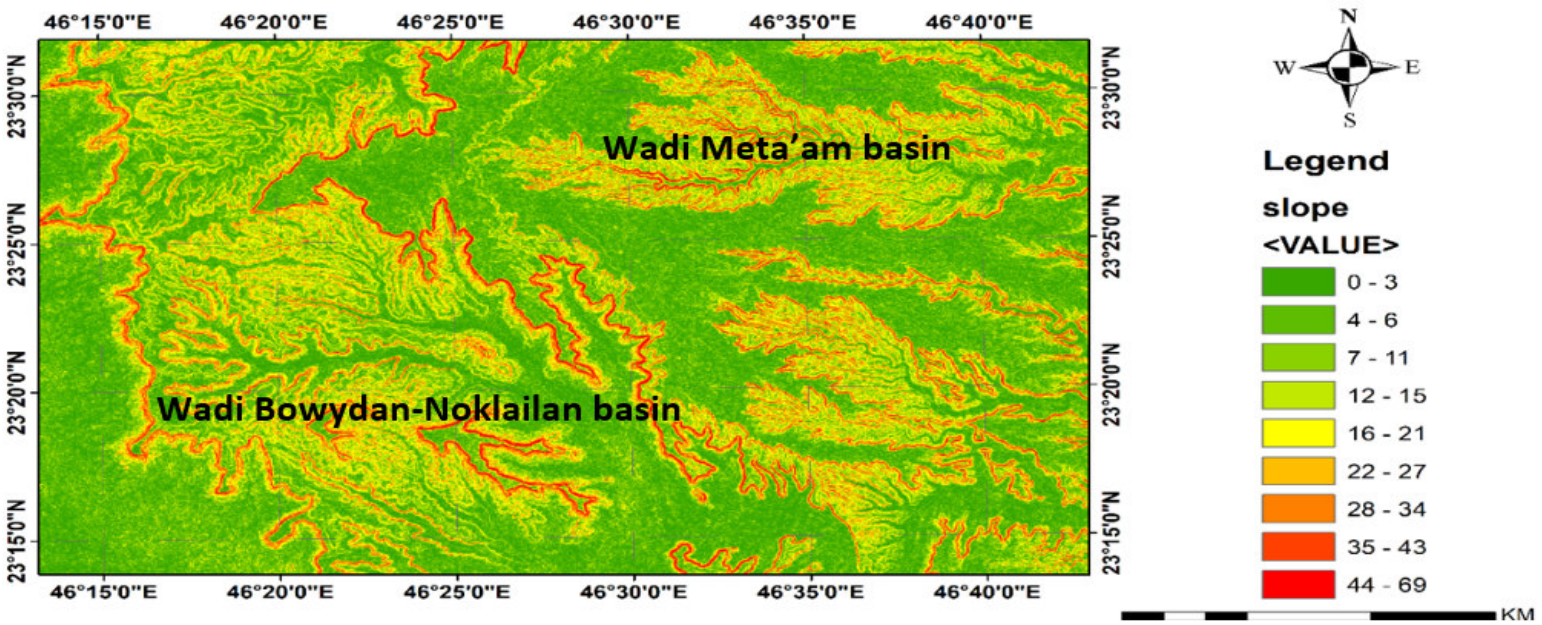

Figure 4. A slop map showing that the plateau escarpment has a slope of $45^{\circ}$, while the basin has a general slope not more than $16^{\circ}$.

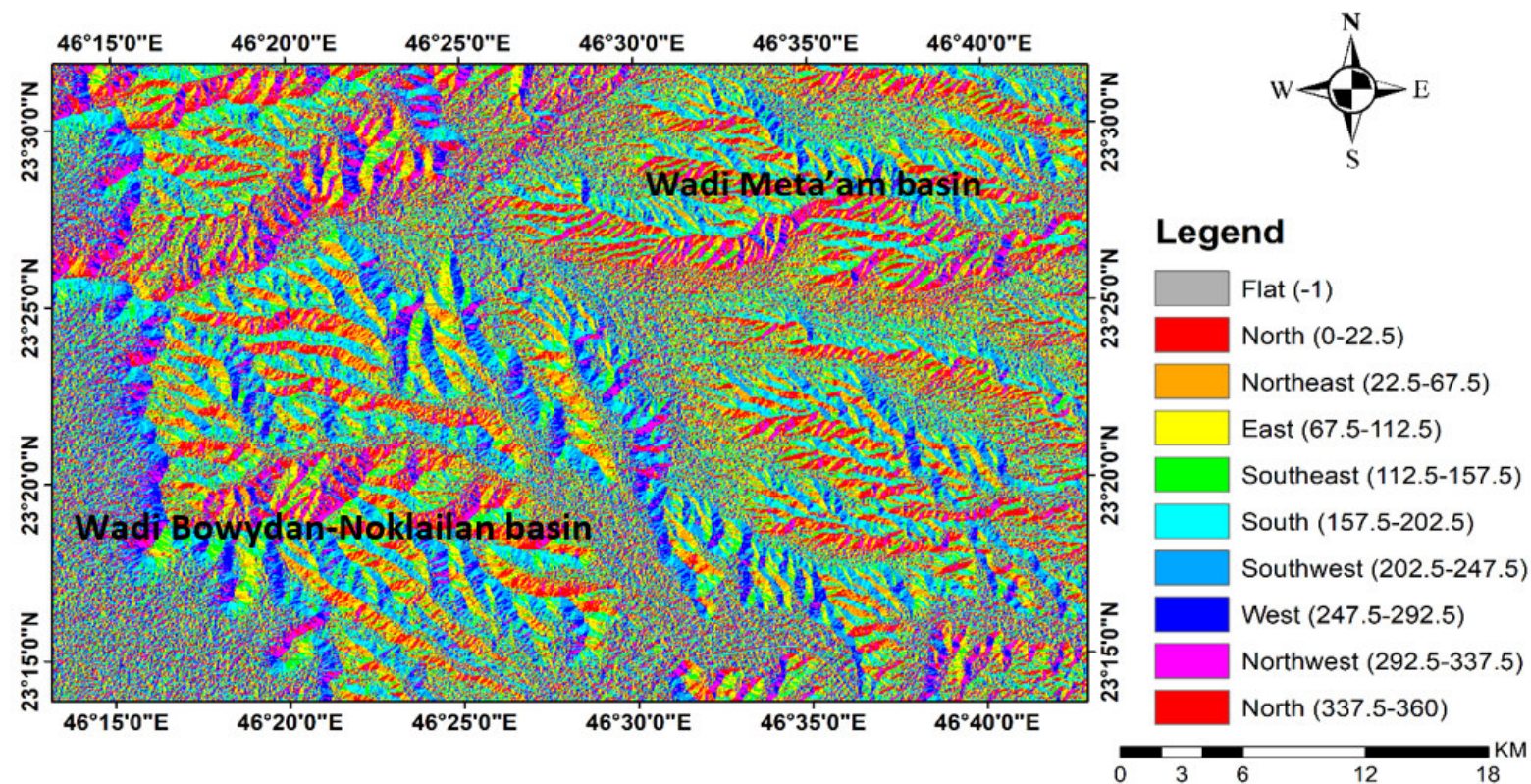

Figure 5. Aspect map showing the E-NE trending tributaries at Wadi Meta'am basin, and the S-SE trending basins of Wadi Bowydan-Nokhailan.

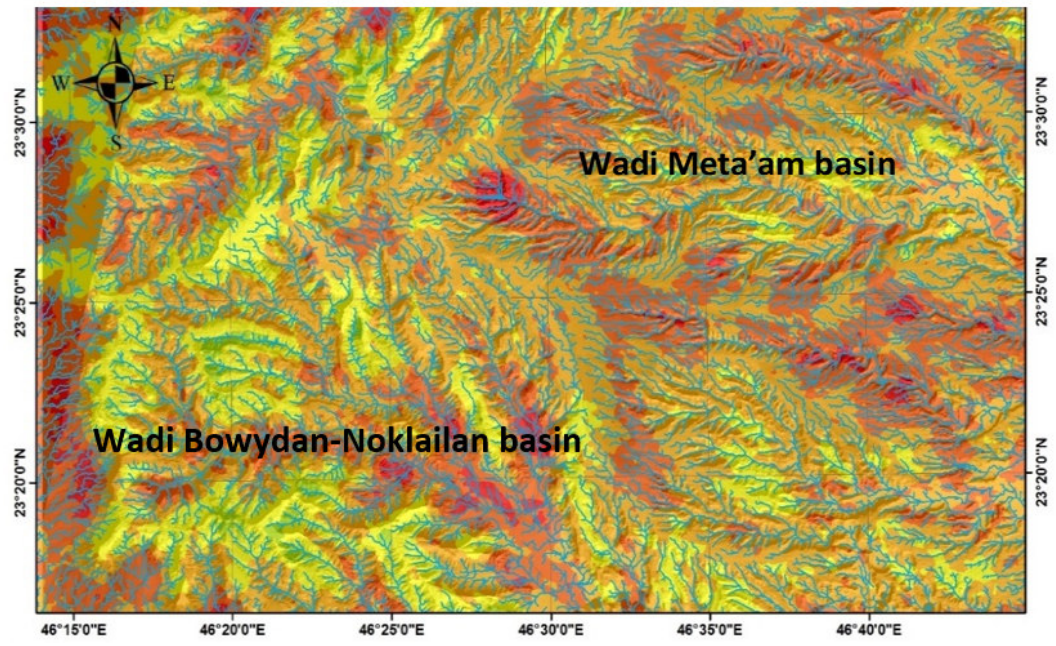

\section{Density map}
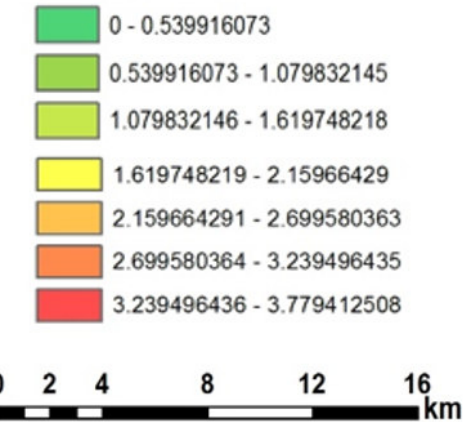

Figure 6. Drainage density ratio map showing the average density ranges from 1.6 to $3.8 \mathrm{~km}^{-1}$. It shows a highly dissected catchment with a relatively rapid hydrologic response to rainfall. 
The Digital Elevation Model (DEM) illustrated that the profile normal to the study area (Fig. 7) shows an average slope of $0.8 \mathrm{cmm}^{-1}$, with step-like escarpment, which suggest contribution of tectonic activities (Fig. 7). The DEM profiles across the two basins, Wadi Meta'am and Wadi Bowydan-Nokhailan are shown in Fig. (8). Wadi Meta'am is narrow with several gullies and at the upstream most gullies show width between $300 \mathrm{~m}$ and $600 \mathrm{~m}$ at downstream, the stream became flat with average width of 930m where the store lake of Wadi Meta'am dam (Fig.8 profiles 1, 2; Fig. 8a). On the other hand, profiles along Wadi BowydanNokhailan basin (Fig. 8 profiles 3, 4, 5), show wider streams, with an average width of $5.3 \mathrm{~km}$, with maximum width of $7.2 \mathrm{~km}$. This study confirms the impact of long-term wet climate with heavy rains that able to sculpt deep stream up to $400 \mathrm{~m}$.

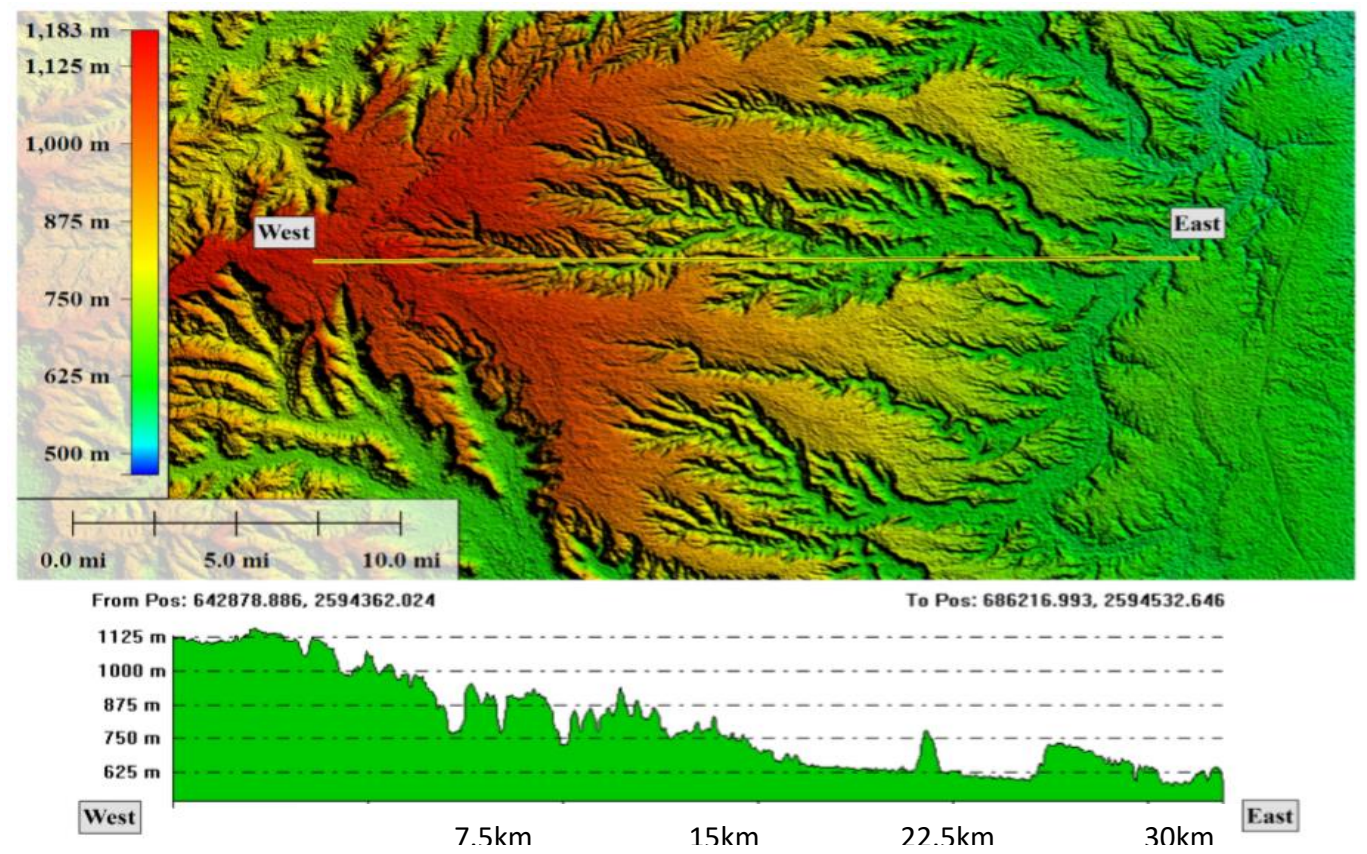

Figure 7. DEM map and profile showing the general slope of the study area from west at Al-Onouk to the east at AlHulwah which calculated as $0.8 \mathrm{~cm} / \mathrm{m}$.

The color composition of Landsat data is used for displaying the data in the image files because these image data are directly associated with the most bright values of the color spectrum. Bands can be systematically assigned to be displayed with either red (R), green $(\mathrm{G})$, or blue (B). For instance, a natural color simulated image will approximate the colors that would appear to the observer of the scene, whereas false colors will allow the analyst to view the data bands that would not appear to the same observer. Bands 7 (red), 5 (green), and 3 (blue) are represented in the composite image data for 2019 (Fig. 1).

The concept of band ratio refers to the mathematical relations and ratios among the available bands within satellite images, and its calculation facilitates the determination of the distribution and intensity of specific features in a semi quantitative way (Drury, 2001, Gaber et al. 2016). Dividing one spectral band by another produces an image that provides relative band intensities, the resulted image enhances the spectral differences between bands. False color composite helps and facilitates the detection of and discrimination between color variations for the exposed rock units without enhancement processes (Mather 1999). The ratio map $(6 / 7,6 / 4,4 / 2)$ for the study area (Fig. 9) was developed by simple division (pixel-by-pixel) of digital values. It shows that, during the rainy season the water saturated soil is clearly distinguished in blue color at the down streams (Fig. 9), while the limestones appear in green. It is also able to distinguish the agriculture fields at the downstream of Wadi Bowydan with yellow wheat fields near Berek and Al-Mikhlaf villages, and at Wadi Meta'am with red palm trees at Al-Hulwah village (Fig. 9).

Principal component analyses (PCA) was employed to compresses information of the original bands and eliminates data redundancy in images by processing different sets of multi-band data; thus, enhancing the discrimination between diverse terrestrial materials (Crosta \& Moore 1989; Loughlin 1991; Dewidar \&Frihy 2003). The resulted false color composites facilitate the detection of variations in land use / land cover (LU/LC), and aid the discrimination between color variations for the exposed rock units without enhancement processes (Mather 1999; Dewidar 2004). Principal component analyses of Landsat-8 data of Ibex protectorate was applied on its bands, and a new set of three-band PC color composites was generated. Input images with false colour composite were used to display all components in the form of PCs. Statistical analysis reveals that PC321 yielded the most positive correlations in bands 321 and 743 for red, green and blue, respectively (Fig. 10). 

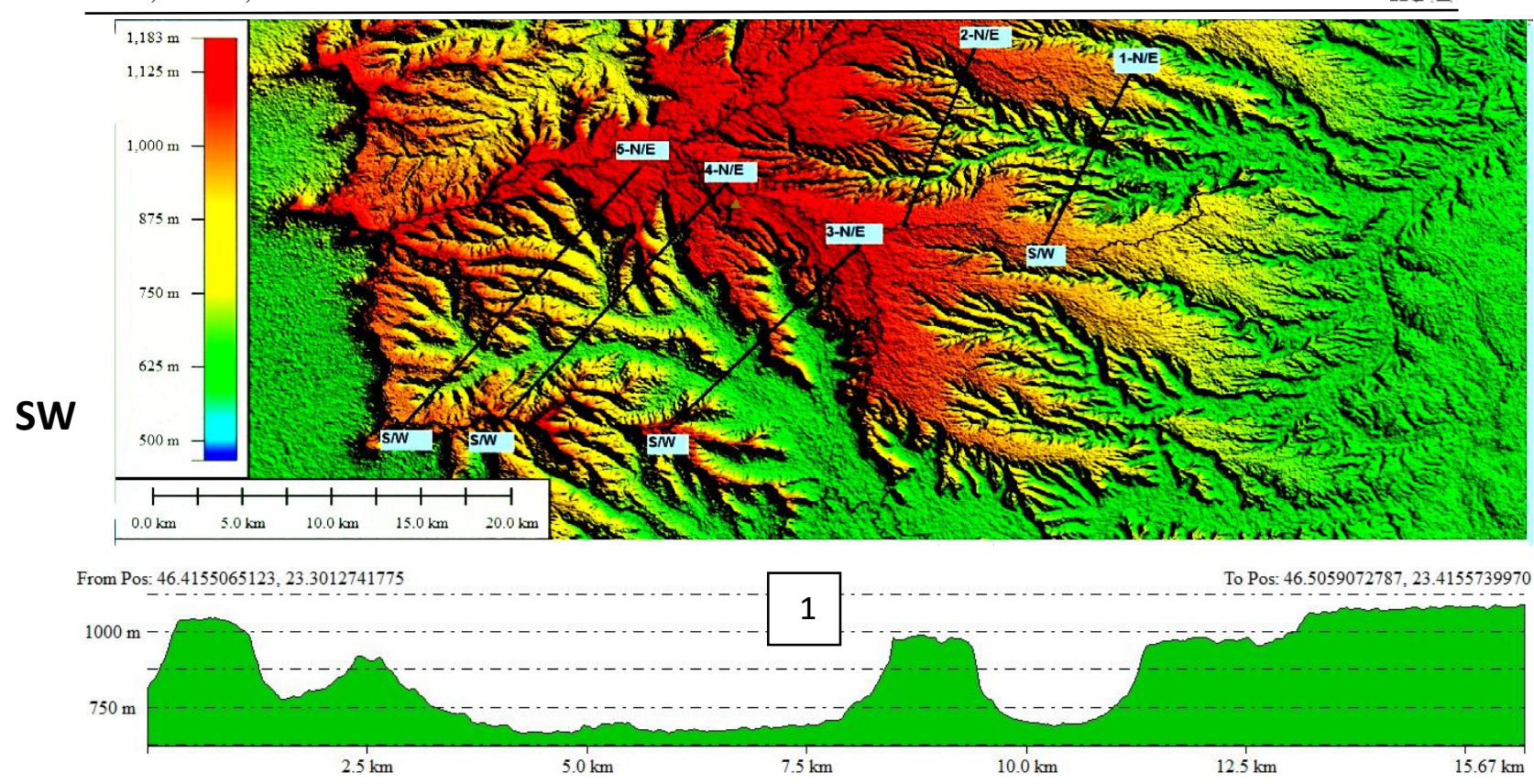

From Pos: $46.6030621252,23.4114176399$
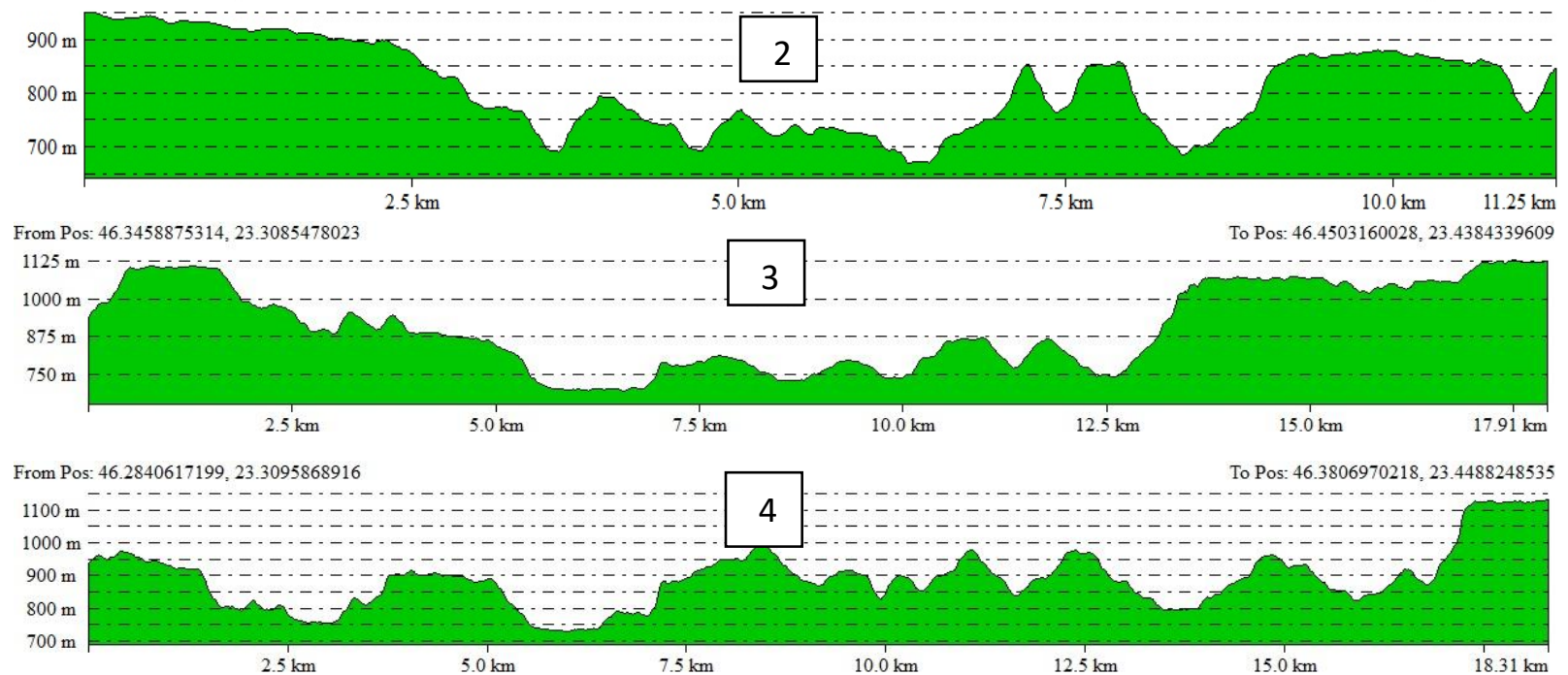

From Pos: 46.5230522516, 23.4202498987

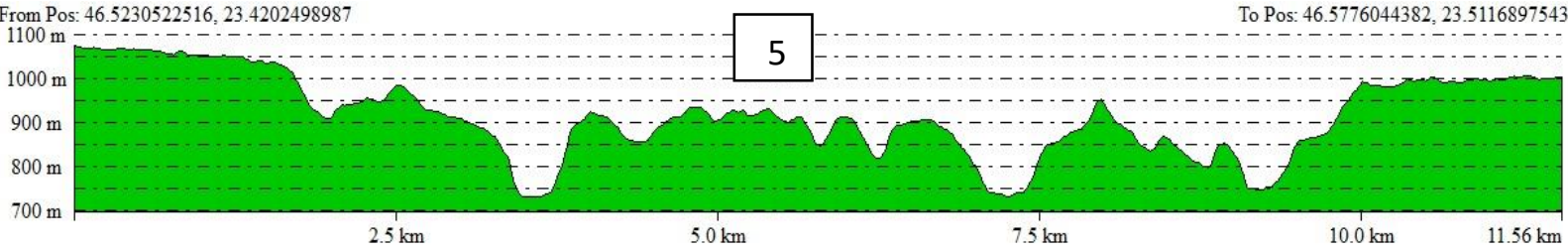

Figure 8. DEM map and profiles across the study area showing the changes in the stream width of profiles 1, 2 (Wadi Meta'am basin) and profiles 3, 4, 5 (Wadi Bowydan-Nokhailan basin)

It shows the tributaries at the downstream, with water enriched sediments in green color and the limestone plateau in a deep red (Fig. 10 a). In contrast, PC 743 for red, green and blue, respectively, shows the upstream escarpment with the slopes and tributaries in yellow and the limestone plateau appears in blue (Fig. 10b).Image classification is widely used as a tool for extracting thematic information of specific targets. In the current study, land use / land cover (LU/LC) and rock units are the main targets to be extracted using a suitable image classification method for LU/LC change detection. This technique is primarily used to display different land categories by arranging image pixels into meaningful groups (Jensen 1995). This mapping process is built upon two statistical methods: supervised and unsupervised (fully automated) image classifications in which classes are either manually supervised or automatically supervised, respectively. 


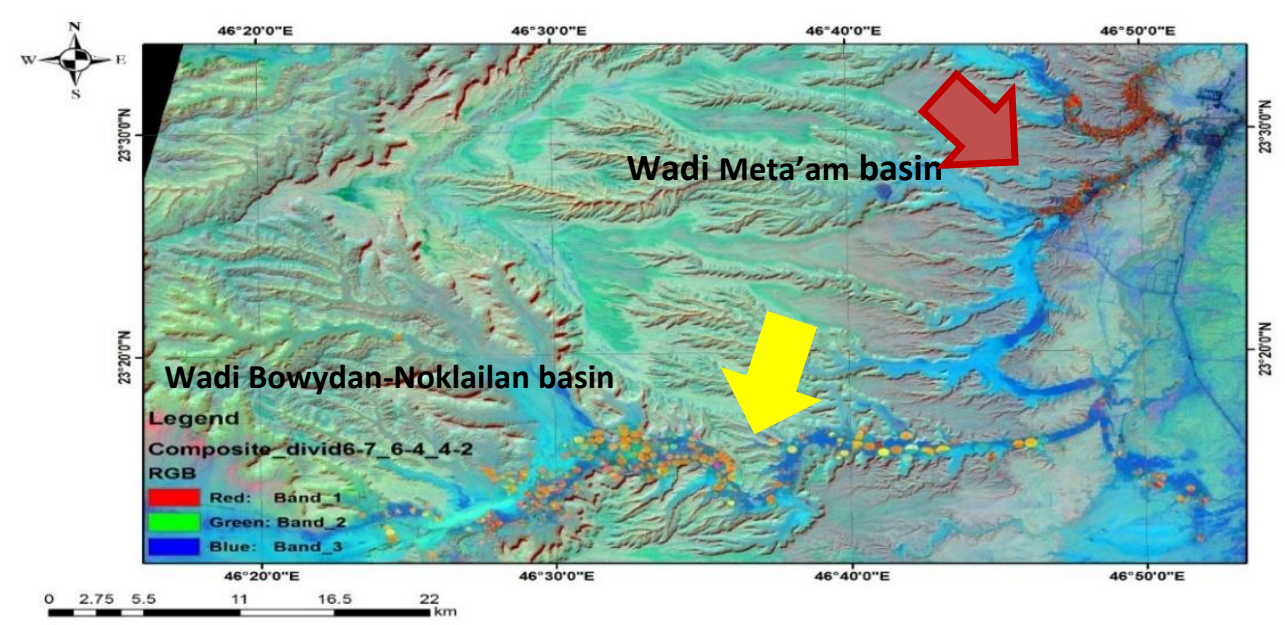

Figure 9. Band ratio map $(6 / 7,6 / 4,4 / 2)$ for the studied area taken during the rainy season showing the water saturated soil (blue) at the down stream of Wadi Bowydan with wheat fields (yellow arrow) near Berek and Al-Mikhlaf villages, and at Wadi Meta'am with palm trees (red arrow) at Al-Hulwah village. The limestone plateau appears in pale-green clearly sculpted by rains during wet seasons.

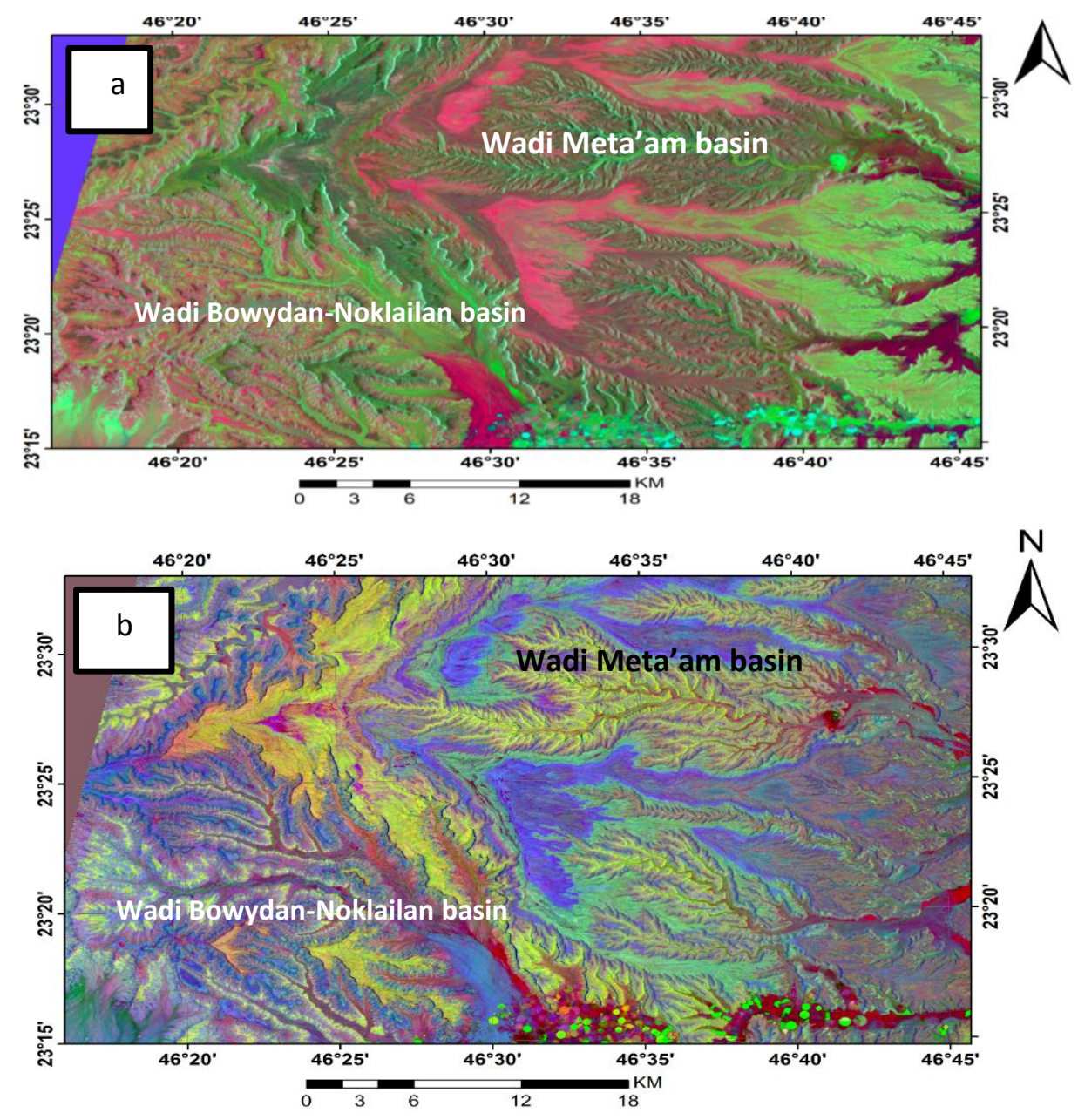

Figure 10. Abu Kaff Upstream 2 Tuwaiq Escarpment 3 Wadi Meta'am basin 4 Wadi Bowydan-Nokhailan basin, 5 the down streams with numerous tributaries. PC321 showing the tributaries with downstream water enriched sediments in green color and the limestone plateau is in deep red (a), on the other hand, PC743 shows the upstream escarpment with the slopes and tributaries appear in yellow and the limestone plateau appears in blue (b). 
Image of unsupervised classification occurred when the computer program controls the analysis, and calculates spectral signatures which then are used in the classification process (Gaber et al. 2016). Each signature is supposed to correspond to a class that does not necessarily represent actual surface features which are depicted by the original image. Fifteen classes are automatically determined where some classes may be merged and others may need to be deleted. The supervised classification, in contrast, analyzes selected pixel groups within the image as to reflect the characteristics of individual classes (Gaber et al.2016). Supervised classification was conducted via field investigation of the study area, during which information from more than 20 ground checkpoints was collected and digital geologic map maps were utilized. Land use / land cover (LU/LC) analysis of the study area reveals six major classes that are related to the Tuwaiq limestone plateau: talus at slopes, calcrete and travertine at top of escarpment, wadi lag detritus, water saturated soil, and Quaternary colluvium (Figs. 2, 11).

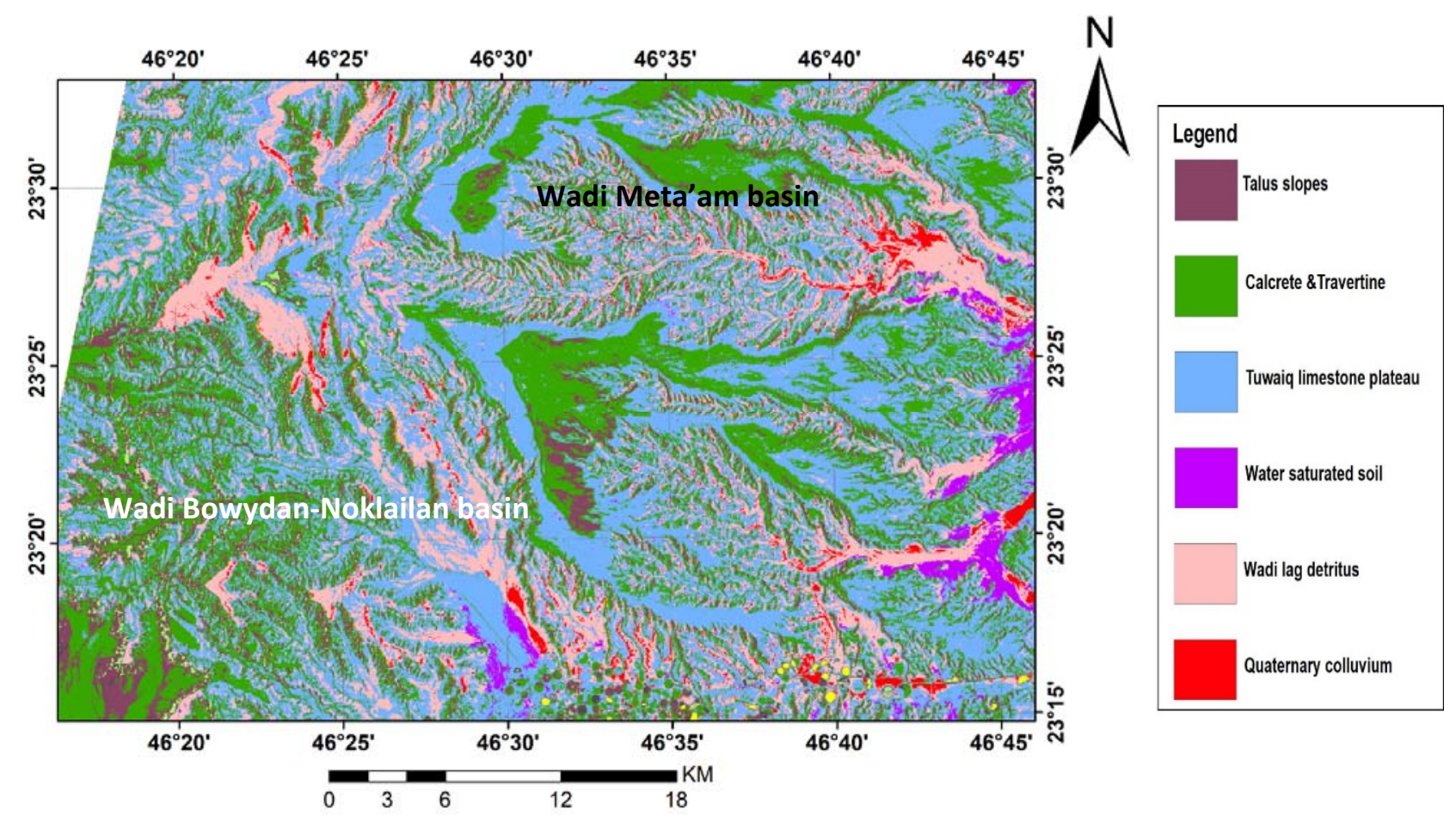

Figure 11. Supervised classification of satellite image for the Ibex Protectorate showing the major sedimentary units at both basins of the protectorate, Wadi Meta'am and Wadi Bowydan-Nokhailan.

\subsection{The flash flood Evaluation}

During the fieldwork, we have been informed that the region of Hotet Bani Tamim is an area of flash flood hazards. This is led us to study the vulnerability of the Ibex protectorate to flash flood via the determination of the watershed boundary and the basins of the region. Using the Hydrological tools in ArcMap, the DEM was first filled for any gaps and the flow direction, flow accumulation, stream order and basin boundaries were identified and obtained from the DEM (Dawod et al. 2012, Farahat et al. 2017, El Bastawesy 2014, Taha et al. 2017).

Wadi Meta'am derives its water through three tributaries Al-Ghaba, Ghafar, and Al-Agmaa (Fig. 1). Wadi Bowydan, on the other hand, cuts deeper and drain water with Wadi Nokhailan downstream to Wadi Berek. (Fig. 1). The areas of all the basins were determined and all the basins less than $100 \mathrm{~km}^{2}$ were eliminated, as they are not big enough to have flooding vulnerability in the region. Accordingly, the study area is classified to 17 basins (Fig. 12). The Ibex protectorate is derived its water from AlOnouk and Abu Kaff high land across two basins Wadi Meta'am basin \#12 and Wadi Bowydan-Nokhailan basin \#15 (Fig. 12). Wadi Meta'am basin \#12 occupying an area of $101.696 \mathrm{~km}^{2}$ and opens into three tributaries, Wadi Al-Agam (5 ${ }^{\text {th }}$ order), Wadi Ghafar (4th order) and Wadi Al Ghaba ( $4^{\text {th }}$ order). On the other hand, Wadi Bowydan-Nokhailan basin \#15, occupying and area of $261.467 \mathrm{~km}^{2}$. This opens into several wadis but the main courses from Wadi Bowydan and Wadi Nokhailan. 


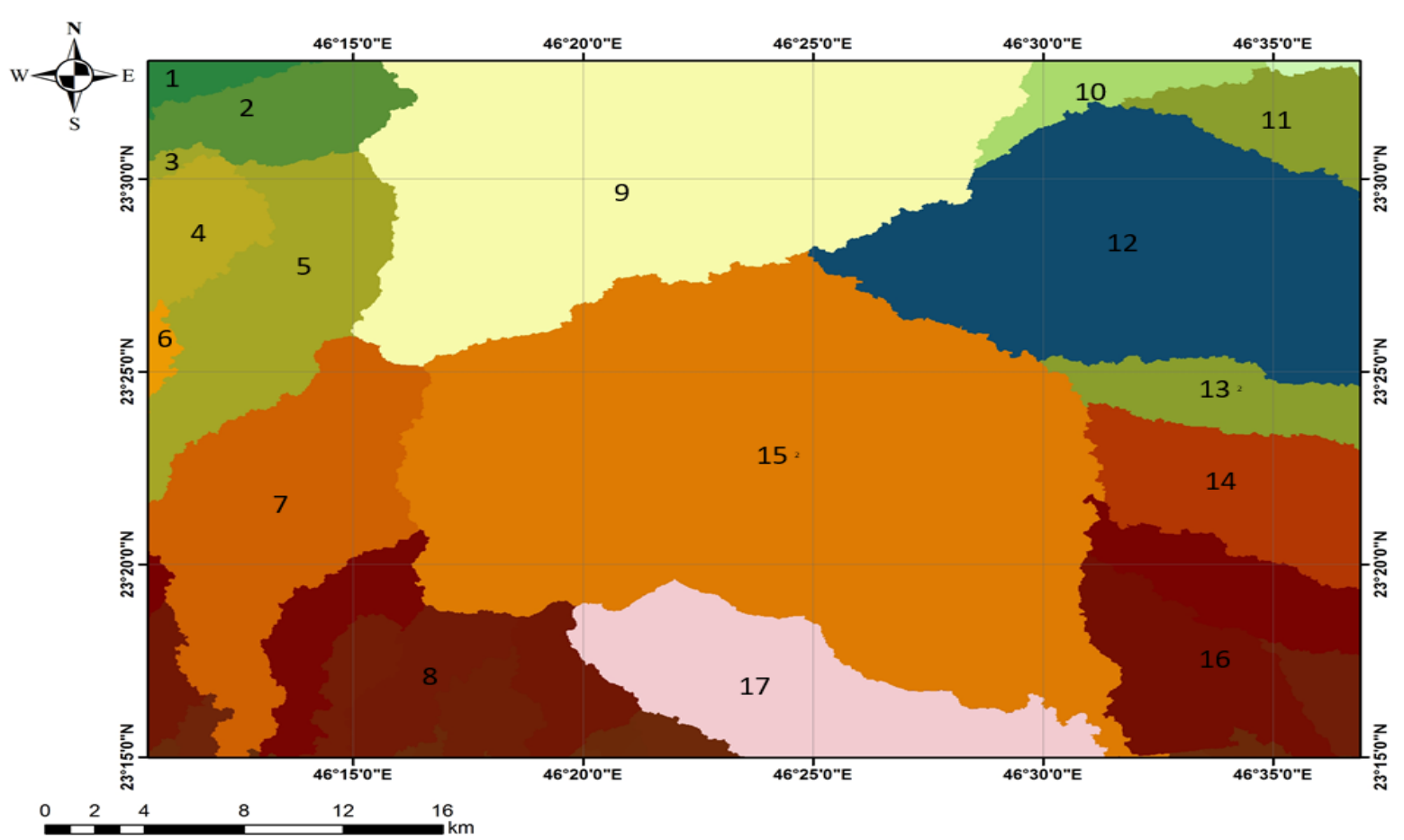

Figure 12. The main basins along the Ibex Protectorate showing the two basins \#12 and \#15 Wadi Meta'am and Wadi Bowydan basins respectively.
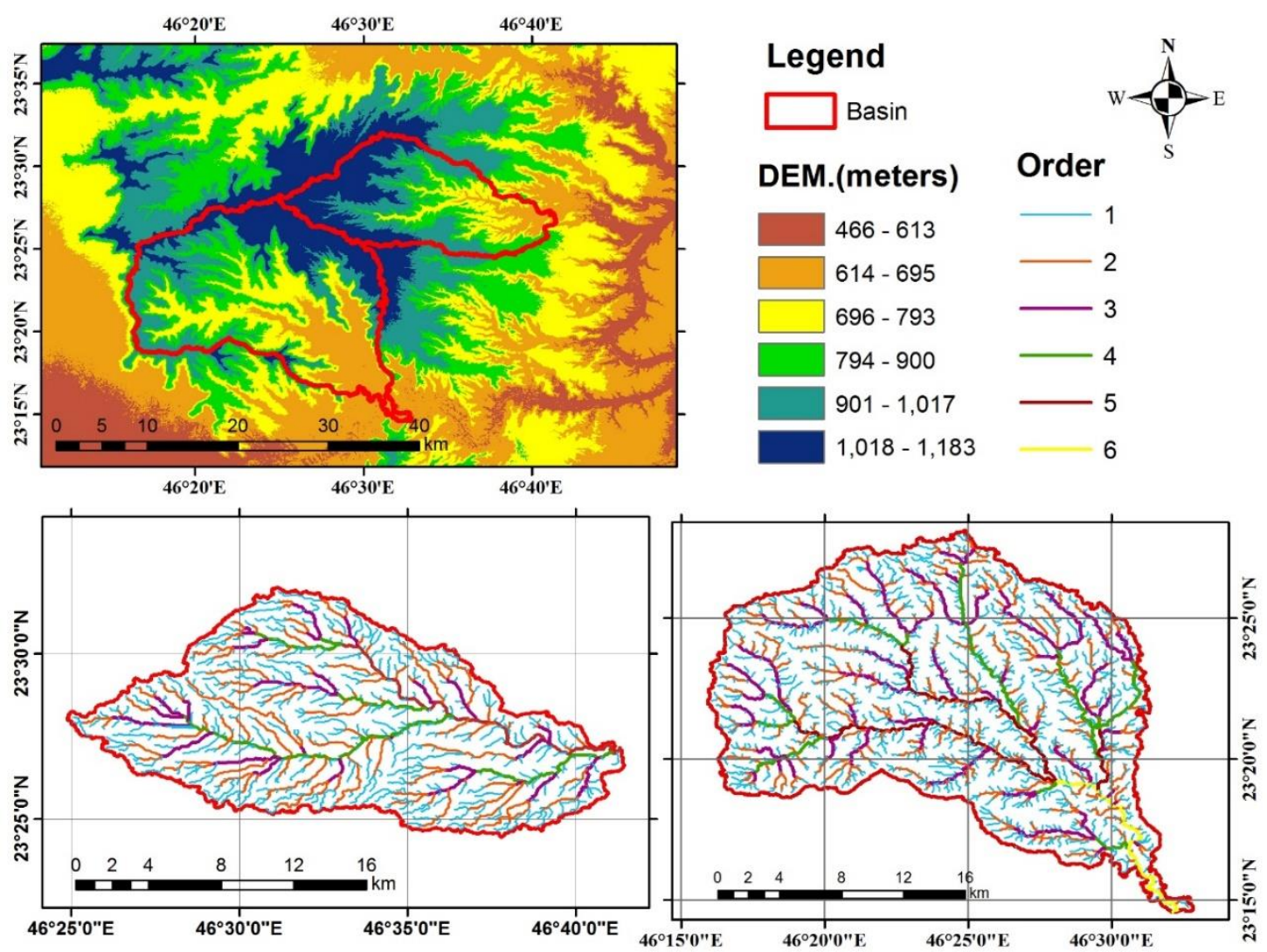

Figure 13. The drainage system and stream orders of Wadi Meta'am basin (A), and the basins of Wadi Bowydan-Nokhilan (B). 
They finally discharged into Wadi Berek (6 $6^{\text {th }}$ order) (Fig. 13), such $6^{\text {th }}$ order tributary at Wadi Berek makes the area flat while receives much quantities of water saturated soils (Figs. 9 and 11) used for agriculture purposes and occasionally suffered from flash floods. While the basin of Wadi Bowydan-Nokhailan is much bigger and receives tremendous amount of water compared with that of Wadi Meta'am basin, the latter suspected to a flash flood vulnerability and form hazard on the Al-Hulwah village a community with area of $33.442 \mathrm{~km}^{2}$. This is in fact due to Wadi Meta'am flows directly eastward to the village, its neck course width is $300 \mathrm{~m}$ in average that makes the water flow is very strong. This made the Ministry of water resources to construct a $930 \mathrm{~m}$ wide dam across Wadi Meta'am course to store 10 milliom $\mathrm{m}^{3}$ of water behind the dam in a lake of 151 acres. However, the lake never receive more than half of this quantity (Qais Al-Haza'a, personal communication). The case at Bowydan appears contradictive the course width is much more higher than Wadi Meta'am, it averaged $5.3 \mathrm{~km}$, and at Wadi Berek reached up to $7.2 \mathrm{~km}$ and opens on a flat agricultural field grow almost wheat at the villages of Massadah, Bowydan and El-Mikhlaf of and area of $99.134 \mathrm{~km}^{2}$.

\section{Conclusions}

The Ibex protectorate is a very interesting geomorphosite, the resulted exquisite fine art painting sculpted due to a natural dialogue between Tethys sedimentation, the tectonic and the climate that were quite adequate to deliver such a unique geodivesity site. Remote sensing applications on satellite images of 2019 were able to measure the geomorphology, distinguish the sedimentary units, and emphasized the role of tectonics in dividing the plateau to step-like escarpment, elevated from $1080 \mathrm{~m}$ at Al-Onouk the extreme northwest to $600 \mathrm{~m}$ at $\mathrm{Al} \mathrm{Hulwah}$ with an average slope of $0.8 \mathrm{cmm}^{-1}$. The slope at catchment reaches up to $70^{\circ}$ while at the downstream not more than $16^{\circ}$. The Ibex protectorate is divided into two major basins; these are Wadi Meta'am basin and Wadi Bowydan- Nokhailan basin, who down flow into Wadi Meta'am and Wadi Berek respectively. Wadi Meta'am derives its water through three tributaries Al-Ghaba, Ghafar, and Al-Agmaa Wadis, while Wadi Bowydan, on the other hand, cuts deeper and drain water with Wadi Nokhailan downstream to Wadi Berek. The high-density $\left(3.1 \mathrm{~km}^{-1}\right)$ dendritic drainage pattern with $5^{\text {th }}$ and $6^{\text {th }}$ order tributaries support the vulnerability of the area to flash flood hazards. The heavy rain was able to sculpt such amazing geomorphosite and leave its finger prints such as deep streams (about 140m depth), channel lags of cobbles and pebbles, Quaternary thick colluvium, water-saturated soils, and karstic features such as the small pool, calcretes and travertines at the top and slopes of the plateau. The present study recommend to introduce this area among the geoheritage sites and to fix on the tourism agenda in the framework of the Kingdom development Vision 2030.

\section{References}

Abbas, A., Khan, S., Hussain, N., Hanjra, M.A., Akbar, S., (2013). Characterizing soil salinity in irrigated agriculture using a remote sensing approach. Phys. Chem. Earth Parts A/B/C 55-57, 43-52.

Abd El-Aal, A., (2017). Identification and characterization of near surface cavities in Tuwaiq Mountain Limestone, Riyadh,KSA, “detection and treatment.” Egyptian Journal of Petroleum 26, 215-223.

Abuelgasim, A., Ammad, R., (2019). Mapping Sabkha Land surfaces in the United Arab Emirates (UAE) using Landsat 8 data, principal component analysis and soil salinity information. Int. J. Eng. Manuf. 7 (4).

Al-Asad, A., (2004). Wadi Hanifa Development Plan. Riyadh, Saudi Arabia. On Site Review Reports, 26pp.

Al-Huquial A., Al-Turki, T.A., (2006). Ecological studies on the natural vegetation at Sabkha Al-Aushaiza in AlGassim region, Saudi Arabia". Saudi Journal of Biological Science, 13, 79-110.

Al-Khamis, H.H., Al-Hemaid, F.M., Ibrahim, A.S., (2012). Diversity of perennial plants at Ibex Reserve in Saudi Arabia. The Journal of Animal \& Plant Sciences, 22(2), 484-492.

Al-Olayan, H.A., (2015). Geo-Environmental Study on Wadi Metaam in the Ibex Protectorate, Central Saudi Arabia. Journal of Environment and Earth Science. v.5, No.4.

Arnous, M.O., El-Rayes, A.E., Helmy, A.M., (2017). Land-use/land-cover change: a key to understanding land degradation and relating environmental impacts in Northwestern Sinai, Egypt. Environ Earth Sci 76 : 263 DOI $10.1007 / \mathrm{s} 12665-017-6571-3$. 
Breeze, P., Drake, N., Groucutt, H., Parton, A., Jennings, R., (2015). Remote sensing and GIS techniques for reconstructing Arabian palaeohydrology and identifying archaeological sites. Quaternary International, 382, pp.98119. 10.1016/j.quaint.2015.01.022.

Carlston, C.W., (1963). Drainage density and streamflow. U.S Geological Survey Professional Paper.

Carrigan, W.J., Cole, G.A., Colling, E.L., Jones, P.J., (1995). Geochemistry of the Upper Jurassic Tuwaiq Mountain and Hanifa Formation petroleum source-rocks of eastern Saudi Arabia. In: Katz, B. (Ed.), Petroleum Source Rocks. Springer Verlag,pp. 67-87.

Chen, H., Ye, S., Zhang, D., Zhang, D., Areshkina, L., Ablameyko, S., (2018). Change detection based on difference image and energy moments in remote sensing image monitoring. Pattern Recognit. Image Anal., 28: 273-281.

Chorley, R. J., (1969). Introduction to Physical Hydrology. Methuen and Co. Ltd., Suffolk, pp. 211.

Crosta, A.P., Moore, J.M., (1989). Enhancement of Landsat Thematic Mapper imagery for residual soil mapping in SW Minais Gerais State, Brazil: a prospecting case history in Greenstone belt terrain. In: Proceedings of the $7^{\text {th }}$ ERIM Thematic Conference. Remote Sensing and Exploration Geology, 1173-1187.

Curran, P.J., (1985). Principles of Remote Sensing. Longman, London, p. 282.

Dawod, G., Mirza, M., Al-Ghamdi, A., (2012). GIS-based estimation of flood hazard impacts on road network in Makkah city, Saudi Arabia. Environmental Earth Sciences 67:2205-2215.

Dewidar, K.M., (2004). Detection of the land use/land cover changes for the northern part of the Nile delta (Burullus region), Egypt. International Journal of Remote Sensing, 25(20), 2004, 4079-4089.

Dewidar, K.M., Frihy, O.E., (2003). Thematic Mapper analysis to identify geomorphologic and sediment texture of El-Tineh plain north western coast of Sinai, Egypt. Int J Remote Sens 24, 2003, 2377-2385.

Drury, S.A., (2001). Image Interpretation in Geology. Nelson Thornes Blackwell Science, Cheltenham Malden, 290.

El Bastawesy, M., (2014). The geomorphological and hydrogeological evidences for a Holocene deluge in Arabia. Arab J Geosci . DOI 10.1007/s12517-014-1396-9.

El Bastawesy, M., White, K., Nasr, A., (2013). Integration of remote sensing and GIS for modeling flash floods in Wadi Hudain catchment, Egypt, Hydrol. Process., 23, 1359-1368.

Eldeiry, A.A., Garcia, L.A., (2010). Comparison of ordinary kriging, regression kriging, and cokriging techniques to estimate soil salinity using LANDSAT images. J. Irrig. Drain. Eng. 136 (6), 355-364.

Erener, A., Düzgün, S., Yalciner, A.C., (2011). Evaluating land use/cover change with temporal satellite data and information system. Procedia Technology 1: 385-389.

Fahmy, A.G., Hassan, L.M., (2005). Plant diversity of wadi el Ghayl, Aseer Mountains, Saudi Arabia. Egypt Journal Desert Research, 55, 39-52.

Farahat, M.S., Elmoustafa, A.M., Hasan, A.A., (2017). Developing flash floods inundation maps using remote sensing data, a case study: Wadi AL-Arish, Sinai, Egypt. American Journal of Engineering Research 6(5):172-181.

Fernández, J.F., Alonso, D.A., González, P.A., (2016). GIS and geoarchaeological analysis in superficial open-air sites: The case of Raña de Cañamero Neanderthal Settlement (Guadiana Basin, Spain). Mediterranean Archaeology \& Archaeometry, 16(2): 47-59.

Foody, G., (2003). Remote sensing of tropical forest environments: towards the monitoring of environmental resources for sustainable development. Int J Remote Sens 24:4035-4046.

Gaber, A., Geriesh, M.G., Shaheen, S. E., Abd El-Fattah, M., (2016). Mapping the Surface Changes in the Area of East Port-Said, Egypt Using Multi-Temporal and Multi-Sensors Remote Sensing Data. Journal of Applied Geology and Geophysics, 4: 19-29. 
Gayen, S., Bhunia, G.S., Shi, P.K., (2013). Morphometric analysis of Kangshabati-Darkeswar Interfluves area in West Bengal, India using ASTER DEM and GIS techniques. Geol Geosci 2(4), 1-10.

Ghoneim, E., El-Baz, F., (2007). The application of radar topographic data to mapping of a mega paleodrainage in the Eastern Sahara. Journal of Arid Environments 69, 658e75.

Hereher, M., Al-Shammari, A., Abd Allah, S., (2012). Land Cover Classification of Hail-Saudi Arabia Using Remote Sensing. International Journal of Geosciences, 3, 349-356.

Herold, M., Scepan, J., Clarke, K.C., (2002). The use of remote sensing and landscape metrics to describe structures and changes in urban land uses. Environ Plan 34:1443-1458.

Jensen, J.R., (1995). Introductory Digital Image Processing: A Remote Sensing Perspective, 2nd edition, Prentice Hall PTR. Journal of Remote Sensing 14, 1359-1370.

King, R.B., (2002). Land cover mapping principles: a return to interpretation fundamentals. International Journal of Remote Sensing data, Remote Sensing of the Environment 86: 530-541.

Lillesand, T.M., Kiefer, R.W., Chipman, J.W., (2004). Remote sensing and image interpretation. John Wiley \& Sons. , 763.

Loughlin, W.P., (1991). Principal components analysis for alteration mapping. Photogramm.Eng. Remote Sens 57, 1163-1169.

Magesh, N.S., Chandrasekar, N., (2012). GIS model-based morphometric evaluation of Tamiraparani subbasin, Tirunelveli district, Tamil Nadu, India. Arab J. Geosci. 11.

Mather, P.M., (1999). Computer processing of remotely-sensing images, an introduction (2nd ed.). Chichester: John Wiley and Sons, 1-75.

Melton, M.A., (1957). An Analysis of the Relations among the Elements of Climate, Surface Properties, and Geomorphology (Technical Report 11). Department of Geology, Columbia Univ, New York.

Monterroso-Checa, A., (2017). Remote sensing and archaeology from Spanish Lidar-PNOA: identifying the amphitheatre of the roman city of torreparedones (Córdoba-Andalucía-Spain). Mediterranean Archaeology and Archaeometry, 17(1): 15-22. DOI: 10.5281/zenodo.258079.

Powers, R.W., Ramirez, I.F., Redmond, D., Elberg, E.L. jr., (1966). Geology of the Arabian Peninsula, Sedimentary Geology of Saudi Arabia. United States Government Printing Office. Washington, 134pp.

Strahler, A.N., (1968). Quantitative geomorphology. In: Faidbridge, R.W. (Ed.), The Encyclopedia of Geomorphology. Rienhold Book Crop, New York, pp. 898-912.

Taha, M.M.N., Elbarbaryb, S.M., Naguib, D., El-Shamy, I.Z., (2017). Flash flood hazard zonation based on basin morphometry using remote sensing and GIS techniques: A case study of Wadi Qena basin, Eastern Desert, Egypt. Remote Sensing Application: Society and Environment 8, 157-167.

Tamouk, J., Lotfi, N., Farmanbar, M., (2013). Satellite image classification methods and landsat 5TM bands https://arxiv.org/abs/1308.1801.

Villela, S.M., Mattos, A., (1975). Hidrologia Aplicada. McGraw-Hill do Brasil, São Paulo, pp. 245.

Vincent, P., (2008). Saudi Arabia: An Environmental Overview. 332pp, Taylor\& Francis. 